\title{
Nordic Noir from Within and Beyond
}

\author{
Negotiating geopolitical regionalisation through \\ SVoD crime narratives
}

\author{
Kim Toft Hansen \\ Department of Culture and Learning, Aalborg University, Denmark
}

\begin{abstract}
In this article, I show how a vision for the Nordic region exists as a banal Nordism, based on years of content exchange, Nordic co-production models, and public funding opportunities. I document how new commercial players have been able to gain a very large market share in only a few years, significantly disrupting the reach of public service broadcasters in the Nordic region. The three largest contemporary commercial players on the Nordic market - Viaplay, HBO, and Netflix - have been able to, in very different ways, tap into the ideology of banal Nordism and the geopolitical unity of the Nordic region, and they have done so by producing and acquiring content that has deep associations with one of the Nordic region's main international brands: Scandinavian crime fiction and Nordic Noir.
\end{abstract}

Keywords: Nordic Noir, geopolitics, online TV, public service, commercial television

\section{Introduction}

As a generic brand, Nordic Noir has been instrumental for the market penetration of various new players and streaming services in the Nordic region and beyond. In various ways, Nordic Noir has influenced the narrative and stylistic development in new television crime dramas, most significantly in pushing crime shows on television from a mostly episodic structure to a serial plot structure, as well as opening a new tendency towards a revised aesthetic of popular television crime series (Creeber, 2013; Hansen, 2020a; Imre, 2018). Of course, Nordic Noir did not come out of nothing, and especially an American and British influence has been noticed, for instance, from NYPD Blue (1993-2005) and Prime Suspect (1991-2006) (Agger, 2011; Nielsen, 2016). Nevertheless, Nordic Noir started as a generic reference to style and content, but the concept has been supplemented by a brand value that may assist in distributing new titles as something intuitively recognisable, yet leaving aside the generic recognisability of Nordic Noir. Although the crime genre is still the heart of the brand name, the British Arrow Films label "Nordic Noir \& Beyond", for instance, quickly went beyond both the crime

Hansen, K. T. (2020). Nordic Noir from within and beyond: Negotiating geopolitical regionalisation through SVoD crime narratives. Nordicom Review, 41(Special Issue 1), 123-137. https://doi. org/10.2478/nor-2020-0012 
genre and the Nordic region in its attempt to brand other films and television dramas for wholesale (Arrow Films, n.d.). Altogether, this clearly underscores how Nordic Noir has become an instrument in the wake of which other titles may attract attention.

However, the rebranding of Scandinavian crime fiction as Nordic Noir in the past decade also carries with it a modified, often unnoticed, geographical reference. While Scandinavia refers to Sweden, Norway, and Denmark, the Nordic region also embraces Finland, Iceland, the Faroe Islands, and Greenland, and from the perspectives of production and distribution, especially Finland and Iceland have received increased international attention in the period since the birth and popularisation of Nordic Noir as a brand from 2010 onwards (Hansen \& Waade, 2017). Based on media policy similarities and various allied parties, the general media system in the Nordic region is even referred to as a common "Nordic media welfare state" (Syvertsen et al., 2014). In popularising Nordic Noir, the dominant public service broadcasters (PSB) in the Nordic region have by far been the most active part in producing and distributing television crime narratives internally in the region and beyond, flaunting that the international attention towards Nordic Noir is rooted in strategic public service ideologies. This involves a range of measures to ensure transnational collaboration in the Nordic region, including a PSB basis underneath a geopolitical intention towards the construction of a common Nordic media culture. Whether or not such Nordic unity essentially exists is not the topic here, but it is very clear that there are strong financial and political forces in the Nordic region intending to strengthen media cultural cooperation within the region.

Especially throughout the past decade, however, the digitisation of television distribution, or so-called "multiplatform television" (Dunleavy, 2018) in "the post-network era" (Lotz, 2007), has increasingly destabilised the stronghold of public service television, including the production and proliferation of Nordic television crime narratives. Quickly, new players have penetrated the market and gained a fair share of the audiences' attention, and one strategic endeavour to do so has been the production and distribution of original or canned crime titles often branded as Nordic Noir. Such a development poses significant questions about the relationship between crime series and geopolitical negotiations, on the one hand, and the role of new players on the market in relation to this idea of a geopolitically integrated region, on the other. What makes crime series such a central force in transnational collaboration? How do new players in the Nordic media ecology use the crime genre in a media environment with shared associations? How do developments within the Nordic crime-narrative culture influence trends outside and inside the Nordic region? In this article, I reply to such questions by analysing how new players strategically use crime narratives as one way among others to attract attention and gain a market share. On the Nordic market, three contemporary players - Netflix, Viaplay, and HBO Nordic - are the dominant subscription video-on-demand (SVoD) services, but they act very differently, and the past few years have slightly altered Netflix's position of power. Below, I describe the current position of PSBs on the market and the importance of crime narratives, turning to the manifestation of the crime genre on three dominant SVoD services in the Nordic region, and lastly I summarise the further perspectives to be drawn from this material. 


\section{Banal televisual Nordism}

Naturally, the presence of HBO and Netflix in the Nordic region has significantly changed the market ecology towards increased competition and new viewing practices for audiences. Such global players now compete with PSBs across northern Europe, and as a consequence of what has been termed "the Netflix effect" (McDonald \& SmithRowsey, 2016), policymakers are now concerned with the destabilisation of the national geopolitical unity intentionally sought by public service media (Bruun, 2018), a common concern also publicly voiced by Maria Rørbye Rønn, managing director of DR in Denmark (Navne, 2015). Even though the market challenges from streaming services have a heavy impact on national PSBs, "traditional" (non-commercial) Nordic PSBs have recently responded by setting up the joint initiative, Nordic 12, where five broadcasters exchange a dozen television series per year with a 12-month window for both linear and streaming services. The commercial PSBs - that is, ad-funded PSB (Ramsey, 2017) have also reacted by setting up SVoDs such as the platforms C More in Sweden, TV2 Sumo in Norway, and TV 2 Play in Denmark - all services clearly using television series as a dominant attraction. In addition, commercial PSBs follow the traditional PSBs in co-producing content with a range of mostly Nordic co-producers; but, in the Nordic region, both traditional and commercial PSBs are now also co-producing drama with their so-called "frenemies", that is, SVoDs with Netflix as the most dominant player (Hansen, 2020 b). Altogether, this indicates that television drama in general plays a very central role in attracting viewers, but for several broadcasters in the Nordic region, especially television crime series have been the go-to genre, revealing that this style of television has a conspicuously cross-national and cross-cultural reach.

Launching Nordic 12, both Rønn from DR and Thor Gjermund Eriksen, managing director of the PSB NRK in Norway, stressed competition from SVoDs as the obvious motive behind the exchange of content, while signaling a common Nordic culture as the basis of an opportunity to challenge especially Netflix's leading position on the Nordic market. According to Rønn:

Drama is the obvious way to reach the Nordic users with content that is about our shared culture and identity, that can bind the Nordic countries across languages and generations. When we, as public service providers, stand together in the Nordics, we simply stand stronger and offer a better offer to the viewers. (cited in Pham, 2018)

It is remarkable how the same content may meet the national requirement of a PSB and at the same time supply the Nordic region with a catalogue emphasising the Nordic region as a united cultural and geopolitical construction. When Robert A. Saunders (2019b: 697), then, defines geopolitical television as "fictional, dramatic video content [investigating] international themes via imaginary scenarios", I wish to stress that such a content approach may well be supplemented with a contextual approach to developments within production cultures and distribution patterns.

In particular, two institutions frame the vision of a common Nordic television culture: first, Nordvision was established in 1959 as an association of five "traditional" PSBs in the Nordic region, and today with four associated members, aiming specifically at establishing "independent cultural political value [translated]" in the Nordic region (Nordvision, 2018:2). Second, the Nordic Council of Ministers, today with 17 traditional PSB and commercial member institutions, set up Nordisk Film \& TV Fund in 1990 in 
order "to promote the production and distribution of Nordic audiovisual works of high quality" (The Nordic Council of Ministers, 2014: 1). Not insignificantly, the ideology behind Nordic 12 is based on several decades of collaboration, as well as regional and geopolitical intentions, establishing what Mette Hjort (2009: 17) has termed "affinitive transnationalism" defined as "a history of interaction giving rise to shared core values, common practices, and comparable institutions". When Saunders (2019a: 987), then, analyses "the transnational social and cultural implications of televisual imaginaries (i.e. built-worlds) where geopolitical emplacement functions as a prominent theme", such themes are suggestively rooted in a Nordic PSB media system as well as what Stuart Burch - recalling Michael Billig's (1995) seminal notion of banal nationalism - refers to as banal Nordism: "a banal, commonplace and unexceptional 'truth' that is unconsciously assimilated, largely ignored and only very occasionally questioned" (Burch, 2013: 136). For Burch (2013: 135), "Norden has long been a 'projection screen for fantasies'[emphasis original]”, an idea echoed in Saunders's (2019a: 987) awareness of geopolitical television's "power to anticipate geopolitical outcomes, and via builtworlds of affect, so prepare polities for future day-to-day realities". In other words, Nordic broadcasters attempt to challenge the market share of global players on the Nordic market by evoking symbols of banal Nordism through the formation of televisual pan-Nordic imagination.

Besides being an international brand name, the potent alliteration in Nordic Noir rapidly revived the attention towards Nordism geographically imbedded in the concept (Nordic Noir) as well as increasing Nordic co-production of content (Hansen \& Waade, 2017). Repeatedly, the Nordic crime genre is sketched as "well-suited for capturing societies undergoing dramatic change" (Stougaard-Nielsen, 2017: 7) with a "focus on (leftist) social and political critique and/or consciousness" (Bergman, 2014: 173). At the same time, Nordic Noir is construed around an internationally recognisable and incredibly popular generic formula, which altogether associates ingredients that have become - for Nordic producers and broadcasters - very powerful in negotiating geopolitical themes through television production and distribution. Rekindling the "Nordic" in Nordic Noir precipitously reiterated visions and interests that, customised through decades of ideological negotiation of televisual PSB collaboration, intensified the already established importance of the crime genre on Nordic screens. However, the question is, then, what happens when transnational, "purely" commercial, and global players tap into such an influential concept and decades of regional branding, furthering the semantics of it with both local and global commercial interests? The sections below show how three significant SVoD players on the market, in various ways, feed on the style, content, and spread of Nordic Noir. Initially, I will analyse the strategies of the pan-Nordic Viaplay service, whereupon I turn to the currently most important global players on the European market: HBO and Netflix.

\section{Viaplay: Universally local crime stories}

At present, television culture is in a complex transition period, with increasing audience attention towards various video-on-demand opportunities, but in contemporary television consumption, linear television has not (yet) been replaced. According to Catherine Johnson (2019: 29): 
[Online television] speaks to the ways in which the newer forms of non-linear and on-demand content and the devices that deliver them are not separate from older broadcast technologies and cultural forms. Rather, the internet era is characterised by the interdependence of television and the internet, and continuities, as well as changes, to television as a medium.

Owned by Nordic Entertainment Group (NENT), Viaplay is an exemplary model of this co-existence of linear and nonlinear television. NENT provides a commercially funded linear television channel (TV3) for the three Scandinavian countries as well as a range of high-profile sports channels in the region, while also offering a free commercially funded streaming service (Viafree) and their main online SVoD-attraction (Viaplay), available in Sweden, Norway, Finland, and Denmark. It is also possible to subscribe to all content in an exclusive "total package". For NENT Chief Executive Anders Jensen, however, this is in hasty transition, as their focus is primarily on streaming and "growth in video on demand", foreseeing that streaming penetration "will continue to increase to closer to 100 percent in the coming years" (Swahnberg, 2018: para. 5, 9). This is a clear indication of a market change towards streaming services, and for NENT, Viaplay is the main product launched in order to compete with the presently powerful Netflix. As a result, NENT has invested heavily in television series, "betting that its Scandi dramas will help it narrow the gap with market leader Netflix" (Swahnberg, 2018: para. 1 ); in other words, it is a huge investment in drama during the past years, aiming at up to 20 seasons of drama each year in a three-year period (personal interview with Nanna Mailand, 25 September 2018). For the average viewer, it is no surprise that drama is the prime content in the fiercely competitive contemporary market, but it is also stressed in viewing figures from Viaplay that it is a worthwhile investment, since the main trend for the SVoD has been original drama (Briel, 2018).

From the present content on the platform, it appears obvious that not just drama in general has been the pursued format, as crime is the ubiquitous genre of the available content (anno June 2020). The first "Viaplay Original" was the crime-comedy series Swedish Dicks (2017), and since then, 35 drama and 12 documentary seasons have been made available for subscribers, among which at least 23 titles would be listed within the crime fiction genre, including Den som drceber [Those Who Kill] (2019), Box 21 (2019), and Det som göms $i$ snö [The Truth Will Out] (2018), clearly alluding to the stylistic features of Nordic Noir. At the same time, the commercial format focus is also indicative in Viaplay's reboot of the Danish TV 2 Nordic Noir series Den som draeber (2011), the acquisition of production rights of a range of Nordic series, including $O k$ kupert [Occupied] (2015-2019) from Norwegian TV2 and Tjockare än vatten [Thicker Than Water] (2014) from Swedish SVT, accentuating an interest in providing the audience with original, yet recognisable, content. In that way, such series become threshold series, as they change the main distribution form from linear television providers to a predominant SVoD service, including branding the earlier PSB seasons of the Norwegian and Swedish titles as original Viaplay series. According to Nanna Mailand, head of originals at Viaplay, the strategy has been well defined from the start:

You may say that if you set a goal to launch 20 series on a yearly basis you tend to begin with a popular genre and a genre that the audience in one way or another is curious about. You could say two things: crime works - crime sells. It does so 
both locally and internationally, and crime series are easier to co-finance internationally. It means that the risk is minimised. It has been a win-win situation in betting on this genre from the start. (personal interview, 25 September 2018)

The crime series Ingen utan skuld [Conspiracy of Silence] (2018) is a case in point. At first, the series appears as a locally Swedish story, but the narrative about corruption in the globalised Swedish weapon trade fits very well with Saunders's procedural-localised type of geopolitical television; at the same time, the series was co-produced based on a Swedish-British-Belgian co-production model. For Viaplay, then, the crime genre is attractive, since it is at once both local and universal:

With this form, I think we have a unique opportunity to stay within the local, within something we may relate to, and within something that people have in common in our territory: Swedes, Norwegians, perhaps not so much the Finns, but nonetheless more so than to many others in the world. Anyhow, there are recognisable patterns that we may reflect ourselves in, but at the same time, we aim for universal narratives. (personal interview with Nanna Mailand, 25 September 2018)

The crime series Rig 45 (2018-) represents this tendency quite literally - as it only takes place on an oil rig in the North Sea, it is a locked-room mystery with a finite number of suspects - but at the same time, the series epitomises a pan-Nordic and British cast as an indicative representation of both the transnational geopolitics of oil trade and the transnational market orientation of Viaplay.

For a "purely" commercial player on the market, a transnational orientation may make sense in the way that it expands production, distribution, and reception opportunities through financing and casting models, something that is common in producing drama for traditional television broadcasters (Hansen, 2020b). However, at the same time, a number of productions for Viaplay have received funding from national and regional funding systems, including The Public Service Fund in Denmark (administered by The Danish Film Institute, DFI), Nordisk Film \& TV Fund, and the Norwegian Film Institute (NFI). For NFI (2019: para. 1), funding is given to productions that "entertain and challenge and stimulate productions of high artistic value and significant cultural and societal value [translated]" while for The Public Service Fund, funding may be granted to "production and distribution of television programmes that in content, form, and expression represents originality, meaning, and quality [translated]" (DFI, 2019: 1). In other words, funding for series may be given if they comply with terms that are usually definitional traits from public service values, while for Nordisk Film \& TV Fund (2019: 4) a project should involve "a special artistic and/or technical effort to promote audiovisual culture in Norden [translated]". Supplementing the commercial agenda of NENT's massive ventures into original television serials, they also apply funding from institutions that may nudge commercial players towards complying with both public service values and the imbedded banal televisual Nordism of the region. Asked about navigating like a PSB, Nanna Mailand (personal interview, 25 September 2018) responded that it may appear as public service, but it could also rather be an obvious way to reach an audience. In other words, creating stories that may both entertain and inform is not only an obligation for a PSB, it has also become a method to gain a regional market share. 


\section{HBO: "Edgy" television feeding the European dream}

For HBO Europe, the market strategy has been markedly different from the expeditious advance of Viaplay. Launched as linear television in Hungary in 1991 and gradually expanding its presence throughout Eastern Europe in the 1990s, HBO Europe is now going through a transition towards intensified streaming in all regions; but, HBO maintains premium channels mainly in Eastern Europe, though increasingly supplemented by local over-the-top services. In the UK and other European territories, Sky Atlantic - providing both linear and non-linear pay television - ensured the broadcast rights to HBO content, running through 2025. At a point in time when various global content players including Amazon and Disney have set up independent global SVoD services, HBO Europe continues a multifaceted strategy that includes distribution rights to and a 2017 co-production deal with Sky Atlantic for some territories, while maintaining local exclusive services especially in Eastern Europe and the Nordic region. In the Nordic region, HBO Nordic was launched in 2012 as an independent SVoD service for Scandinavia and Finland, but recently, HBO Europe and HBO Nordic came under common leadership from the main European office in London, which may express a tendency towards HBO growing power to expand their services across Europe. Compared with Viaplay's expansion in the Nordic region, HBO's European strategy has rather been a slow, steady, and gradual development over almost three decades.

HBO's presence on the Nordic market has been equally unhurried as we, at the time of writing, have just seen the first two original Nordic productions: Lukas Moodysson's Swedish-language Gösta (2019) and the Norwegan-language sci-fi-crime series Fremvandrene [Beforeigners] (2019). At present, two additional series (one Swedish and one Danish) are in development, while until now, content on the HBO Nordic platform has been HBO productions from other places, including their globally marketed American content and series produced for Eastern European territories. Rather, the impact of Nordic Noir on HBO must be located through productions for the Eastern European territories where trends and themes of the serials, as documented by Aniko Imre (2018) and myself (2020a), are directly associated with Nordic crime shows. The Norwegian crime serial Mammon (2014-2016) was remade twice as the Polish Pakt [The Pact (2015-2016) and the Czech Mamon (2015), while the Hungarian serial Aranyélet [Golden Life] (2015-2018) was based on the Finnish crime serial Helppo elämä [Easy Living] (2009-2011) (Imre, 2018). In addition, the Romanian remake of the Norwegian crime series Øyevitne [Eyewitness] (2014) as Valea Muta [The Silent Valley] (2016) also highlights a significant orientation towards Nordic crime narratives, emphasising a very literal adapted influence from Nordic crime serials. However, Imre also observes that the Romanian Umbre (2014-) rests on "the realism of Nordic noir" (2018: 60), while she misses the very literal intertextual relationship between the Czech Pustina [Wasteland] (2016) and Forbrydelsen [The Killing] (2007-2012) (Hansen, 2020a). The aesthetics and narrative strategies of Nordic Noir, including slow-paced storytelling, dimmed lightning, and melancholic characters and atmospheres, are all comprehensively appropriated into the Eastern European serial productions. For HBO Nordic, according to the head of original programming Hanne Palmquist, the strategy appears to be different from HBO's Eastern European activities, since "there have been - and there most likely still will be - made so many crime shows in the Nordic region; it is almost like a defining genre for us, right?" (personal interview, 11 January 2019). Much in line with 
HBO's branding model, Palmquist insists on originality and "edgy" drama that stands out from the Nordic mainstream, and when Nordic Noir has become mainstream for both linear broadcasters and non-linear SVoD services, "it may not be as innovatory to venture in that direction" (personal interview with Hanne Palmquist, 11 January 2019).

Even if that is the case, Palmquist recognises that one of the dramas produced for the Nordic audience clearly has an interface with the crime genre. Beforeigners "contains a crime-engine, while the first two Swedish series Gösta and Beartown represent other genres" (personal interview, 11 January 2019). Of course, a "crime-engine" does not convert Beforeigners into Nordic Noir, but it still maintains the influence and manifestation of the Nordic crime genre on the contemporary European streaming market, including a dark or dimly lit aesthetics and a police-procedural plot. When asked about the extent to which HBO compares with a PSB, Palmquist highlights that HBO's main motivation is producing "edgy, redefining, and thought-provoking drama for a local Nordic and secondarily for an international audience, and to an extent that PSBs do not have same mandate to do in order to comply with national public service remits" (personal interview, 11 January 2019). However, when small-nation dramas from, for instance, Denmark, travel internationally, the audience of the dramas become very similar to the typical audience of HBO. According to Pia Majbritt Jensen (2016: para. 1):

There are clear indications that the further the series move away from Denmark (both in regards to culture, geo-linguistic regions and media systemic models), the more "niche," quantitatively speaking, the importing channels become. This does not mean, however, that the series do not have an impact because the foreign channels that have acquired the drama series in question tend to appeal to audiences that are likely to include the more influential and trendsetting segments of the population; that is, the segments with a high cultural, intellectual and possibly financial capital.

This means that the international profile of HBO's dramas and series from the Nordic region may acquire a very similar cosmopolitan market position when travelling transnationally, and that Nordic PSB values and the market interests of HBO are not that different.

For Aniko Imre (2018), HBO Europe plays a decisive role not in establishing national or regional cultural unity, but rather a model for transnational, transcultural European identification. While "organically connecting with European trends such as Nordic Noir, HBO's status and mobility [...] highlights similarities among audience sensibilities in the small nations of postsocialist Eastern Europe and the small nations of state socialist Scandinavia" (Imre, 2018: 60-61). Through mainly online television distribution and an expressively localised series (on-location shooting and a substantial awareness of local colour), Imre claims that HBO creates an "e-EUtopia", that is, an e-distributed sense of European connectivity:

HBO Europe is a perfect agent and platform for navigating a European landscape where media regulation promotes digital connectivity and yet undermines small nations' competitiveness and effectively leads to the fragmentation of domestic markets. It has successfully broken down (or ignored) the seemingly intractable divide between national and supranational identifications. It has designed and implemented a pan-European approach that envelopes the European tradition 
of public service broadcasting, art film, and documentary in its elastic "quality" brand and offers stories, themes, characters, and styles that qualify as "originals" in specific national contexts while they travel easily from market to market precisely because they consist in shared European and global narratives that have become even more hybrid and homogeneous thanks to digital platforms of borderless internet distribution. (Imre, 2018: 62)

At a time when European unity is significantly under pressure, an American global media player appears to, at least, feed the dream of a shared culture in the geopolitical region of Europe through local productions distributed to SVoD subscribers across the region, although the market position of HBO in Europe may be slightly overestimated in Imre's work. However, the point here is that the generally European localised model for nourishing the European ideology of geopolitical unity has been directly influenced by Nordic Noir.

\section{Netflix Noir: Canned acquisitions and "originals"}

While HBO has been able to manage a distinctively narrower niche approach to online content, Netflix has to a larger degree aimed at a much more mainstream audience, which may be the reason why Netflix is the contemporary spearhead of streaming services in the Nordic region. Netflix started as an online video rental service in 1997, but due to a declining DVD market, the service supplemented rental with online streaming ten years later. As Sheri Chinen Biesen (2016: 131) notes:

Throughout its early history, Netflix was known for its Long Tail approach [...] as a DVD-by-mail service, it distinguished itself from leading video chains like Blockbuster by offering a broader overall selection, a deeper catalog that emphasized older films and genres like film noir.

Basically, the present Netflix SVoD service and the use of algorithmic logic in "pushing" titles to customers is no different, and the varying online catalogue of titles on the Netflix platform still include a long tail of titles within different so-called altgenres, including a number of specific altgenres related to Nordic Noir such as "raw Nordic noir", "Nordic noir about revenge", "emotional Nordic noir", and "nerve-racking Nordic noir based on books", among others. Searching for Nordic Noir (without quotation marks) on the Danish Netflix platform presents the user with a number of series and films that would normally be associated with the brand, including Bron/Broen [The Bridge] (2013-2018) and Ófærð [Trapped] (2015-), but the search algorithms based on users' play and search data, as well as metadata, also retrieves a compelling number of non-Nordic titles that have been explicitly credited as inspired by Nordic Noir, including the Welsh Y gwyll [Hinterland] (2013-) and the English Broadchurch (2013-2017). Besides the use of a brand name as a search method, this indicates that there are a number of salient stylistic and metadata features that services the user with similar content also included in the "video-video similarity algorithm" represented in the "Because You Watched" row on a user's personal Netflix account (Gomez-Uribe \& Hunt, 2015). However, if you follow the altgenre "Nordic Noir" (with quotation marks) it leads you to a selected number of titles that actually follows the geographical reference in the brand name; now, the titles 
retrieved are only titles produced in the Nordic countries, indicating that the geography of the brand and genre is in part an important aspect of its market position. In other words, for Netflix, the brand Nordic Noir has become one market strategy among many.

The position of Nordic Noir within the vast catalogue available on different territorial Netflix services may not only be read through the different titles available, but also through the way Netflix acquires and co-produces content from and with Nordic producers and broadcasters. Through the reference to "Netflix Originals", Netflix vigorously uses its brand name as a qualifier of content that has not been produced or co-produced solely by itself. Instead, the platform actively blurs the boundary between titles created by Netflix and titles only acquired by it. This was recently discussed in The Guardian related to the BBC production Bodyguard (2018) (Hughes, 2018), but it is also the case within the altgenre "Nordic Noir" where the two recent Finnish crime series Sorjonen [Bordertown] (2016-) and Karppi [Deadwind] (2018-) have been branded as Netflix Originals even though Netflix acquired them through canned sales. The strategy described in relation to Viaplay - that is, picking titles from traditional broadcasters in order to produce further seasons within the same franchise - has been a Netflix strategy too; for example, the Spanish series La casa de papel [Money Heist] (2017-) or the American Nordic Noir remake The Killing (2011-2014). One may claim that Netflix, in this way, struts about in borrowed plumes, but the organisation also produces Netflix Originals in two other ways that may be considered less contentious. For Netflix, the first "original" venture was the co-production of crime-comedy Lilyhammer (2012-2014) with the Norwegian PSB NRK, indicating an early interest in the Nordic region as well as the Nordic crime genre, and they recently co-produced the crime serial Kriger [Warrior] (2018) with the Danish commercial PSB TV 2 (Hansen, 2020b). Co-producing the Nordic Noir-stylised Hotel Beau Séjour (2017-) with Belgian broadcaster Éen stresses the international influence of the brand and style. For these institutions, the obvious reason for co-producing is minimising the commercial risks in creating expensive original content, although the position of Nordic crime within such co-production ventures is significant; for Netflix, Nordic Noir crime dramas have been just as safe a bet as for other producers and broadcasters. Unmistakably, there has been a direct market value in being associated with the brand Nordic Noir.

The market value is also prominent in a number of serials fully produced for Netflix without local broadcasters as delegate producers. The first Danish original production The Rain (2018-) is, at its root, a youth drama rather than the typical police investigation in Nordic Noir. Yet, the dark aesthetics of the drama, the fact that the plot obviously revolves around rain, and the use of Scandinavian forests as locations, are all traits that are recognisable as Nordic Noir. Just like The Rain, the first Swedish Netflix series Störst av allt [Quicksand] (2019-) is a youth drama, but at the same time it embraces a crime drama and a style similar to notable titles within Nordic Noir; through the creator Camilla Ahlgren, a well-known figure within Swedish crime-series production (including The Bridge), the promotion of the series directly associates Quicksand with Nordic Noir. The first original German Netflix production Dark (2016-) also tweaks the style and narrative of Nordic Noir in an attempt to both attach and detach itself from the brand name, but I have elsewhere documented the direct affiliation between the series and Nordic Noir, especially The Killing (Hansen, 2020a), while Dark - like both Quicksand and The Rain - also integrates a youth plot in the narrative. These three series directly 
associated with Nordic Noir not only suggests that genre has been an influential style that may be used as a market penetrator, also for Netflix, but the appropriation of the stylistic and narrative traits of the brand into an accentuated youth plot also indicates who a leading Netflix audience presently appears to be - a younger audience than HBO's.

Altogether, Netflix employs four different ways to present series as "original" through the platform: 1) the Bodyguard model (branding of exclusive acquisitions as original content); 2) the Money Heist model (acquisition of production rights); and 3) the Lilyhammer model (co-producing content with local players) and the House of Cards model (commissioning own "originals"). In this way, Netflix has been able - among many other market strategies - to exploit the popular brand Nordic Noir in ways that appear suitable for the platform's online strategy and identity. At this stage, Netflix has not (yet) received or applied for public funding for their dramas, but co-producing series with Nordic commercial PSB makes Netflix indirectly comply with the public service obligations of such institutions, and by acquiring series after being broadcast on PSBs, Netflix still creates and profits from a long tail of mostly Nordic commercial public service dramas.

\section{Opportunities and threats in streaming a shared culture}

As Viaplay, HBO Nordic, and Netflix in very different ways directly tap into a common construction of the Nordic, they all also leave a symbolic trace of banal Nordism. For Netflix, the Nordism algorithmically reverberates through titles embraced by their altgenres related to Nordic Noir, and even though the reach of their available titles is unclear and unavailable to researchers, the mere availability of the material, at least, serves as an opportunity for Nordic Netflix users to gauge Nordic titles in a way similar to what the above-mentioned Nordic 12 arrangement intends (although, not as freely available through linear and non-linear services as for the traditional PSBs). Both HBO and Viaplay engage much more directly in local and regional policy arrangements by applying for and receiving public funding for the productions based in the Nordic region. In general, though, all three market players have actively engaged themselves in the local colour of the Nordic region through the use and construction of local and regional narratives, selecting recognisable locations in the region (including the dark-humoured use of Astrid Lindgren's Småland as a location for the Swedish HBO-drama Gösta) and locally and regionally oriented casting models. In fact, to a wider extent than traditional and commercial PSBs, still primarily with national public service obligations, these commercial players engage deeply in production and acquisition of local content throughout the whole Scandinavian or Nordic region. The result may be a market-based geopolitical construction of a sense of Nordism centralised around an assumption about a shared culture and identity.

Commercial players such as these do not enter the ideology of banal Nordism in order to strengthen the shared culture in the Nordic region, but rather, they play along with the cultural narrative with the intention of strengthening their position on the Nordic market (and with Nordic drama acquiring an international reputation, even also on the global niche market). Significantly, this resembles what Mette Hjort (2009: 19) has termed "opportunistic transnationalism [that gives] priority to economic issues to the point where monetary factors actually dictate the selection of partners beyond national borders". Nevertheless, this market change may be only slightly different from 
the various market changes throughout the Nordic region during the 1990s. In 1988, 1991, and 1992, respectively, the commercial PSBs TV 2 Denmark, TV2 Norway, and Swedish TV4 were set up as an alternative market competition to the traditional PSBs. The intention was to strengthen private production of media content in Scandinavia, and the result was a significant rise in the number of production companies producing content for the commercial PSBs as well as a considerably different market orientation among the production companies. Especially in Sweden, the television producers were able to take advantage of a rising wholesale market - firstly in the VHS format, later in DVDs- as a window that slowly developed itself between production and broadcast of the content. In Scandinavia, this really started with Filmlance's successful adaptation of the characters from Mai Sjöwall and Per Walhöö's Beck novels into Beck (1997-). Together with Anne Marit Waade (2017), I have dubbed this construction "the Beck model", and as pointed out by Steven Peacock (2014: 62), and which I further developed with Waade, this period with the intensified competition from commercial PSBs resulted in a blurring of the boundaries not only between novels and screened adaptations, but also between cinema, wholesale, and television broadcast. Since the IP of the productions was retained by the production company, the same nine-minute Beck film could make it to the Swedish cinemas, reach VHS and DVD distribution, and lastly end as a television series (after cinema release, it would be more than two years before the first Beck film was broadcast on Swedish TV4). Essentially, some of the most successful examples of what is now termed Nordic Noir - such as Beck and later Wallander (2005-2013) - were based on a public service model with a commercial pedigree, which means that these titles were neither framed only by traditional public service values nor introduced as pan-Scandinavian co-productions in order to strengthen the geopolitical construction of the Nordic region. The end goal was market profit within a framework built around public service values and public funding opportunities.

The point with the reference to the Beck model and the changes in the 1990s Scandinavian media ecology is that something comparable is now happening again. As mentioned above, television consumption today is increasingly dependent on the Internet, and guided by new concepts like "online TV" (C. Johnson, 2019), "multiplatform television" (Dunleavy, 2018), and "app-delivered television" (D. Johnson, 2018: 6), we now see television integrated in online services such as streaming platforms, social media, and traditional websites. Since the birth of television,

television is a hybrid medium that has been subject to seemingly endless change. Yet the internet era that has emerged since the late 2000s has been particularly disruptive to accepted definitions of television as a medium [where] multiple different forms of audiovisual content are delivered through a dizzying array of technological infrastructures [...]. One consequence of this is that previously normative assumptions about what counts as television come under threat. (C. Johnson, 2019: 30)

On the one hand, such a history of television as a medium does not necessarily indicate that the sheer presence of commercial players - such as Viaplay, HBO, and Netflix - as such threatens the opportunity to comply with intentions embedded in public service values, objectives in Nordic collaborative institutions, or the intricate connotations of banal Nordism. 
On the other hand, what critics of the Netflix effect and the disruptive exertions of global "purely" commercial players - such as the above-mentioned Maria Rørbye Rønn as well as the raison d'être behind The Audiovisual Media Services Directive (AVMSD) from the European Union - react to is rather the lack of control from authorities of the provision of content. The above analyses of the three main SVoD providers in the Nordic region show that popular screen culture may involve a bottom-up process in the way that audiences seek out predominantly recognisable content, which also includes culturally familiar content produced in and for a specific country or region. Right now, the AVMSD from the European Union is being implemented on a continental level (prone to local adjustments), and the issue that has been mostly debated is the demand from the European Union that global players such as Netflix must provide each territory with local content (European Commission, 2018). According to The Hollywood Reporter, however, Netflix is still far from producing enough content to comply with the European Union Directive, even though they have amped up the production of local content (Roxborough, 2018). This means that the increase in local content from these global players during the past few years may not only be based on the commercial logic behind creating "what people want", but it may very well also be a way to ensure compliance with a fully implemented AVMSD in 2020. However, if the intention is to strengthen local content on platforms like HBO and Netflix, the threat towards both traditional and commercial PSBs may end up being even greater, since the media conglomerates are forced into producing content that has been the home-turf of PSBs. As the above analysis documents, large transnational content providers have the power to seize a cultural trend, established on PSB values like Nordic Noir, and turn it into a profitable business model on both a local and a global online marketplace.

\section{Conclusion}

In this article, I have shown that a vision for the Nordic region exists as a banal Nordism, based on years of content exchange, Nordic co-production models, and public funding opportunities. I have also documented that new commercial players have been able to gain a large market share in only a few years, significantly interrupting the reach of PSBs in the Nordic region. The three largest contemporary commercial players on the Nordic market, Viaplay, HBO, and Netflix, have been able to, in very different ways, tap into the ideology of banal Nordism and the geopolitical unity of the Nordic region, and they have done so by producing and acquiring content that has deep associations with one of the Nordic region's main international brands: Scandinavian crime fiction and Nordic Noir. This highlights the crime genre as a very important popular genre that may assist different market-oriented players in penetrating markets that already have a strong tradition for serial-drama content production. The result is a creation and curation of a very large catalogue available to local and transnational audiences, including content adhering to Nordic local colour and banal Nordism, as well as a long tail of accessible titles. However, of course such a market logic may end up hiding publicly funded content behind a paywall, which may be contrary to the intentions behind funding the production of local content, even though such a consequence may be implied within a general commercialisation of PSB content, at least for the commercial PSBs in the region. New European policies on content quotas attempt to neutralise the impact 
of global players by forcing them to produce local content, but as noticed above, this may not be as straightforward as intended. The commercial players have quickly proved themselves very apt in adopting new trends from PSBs - with Nordic Noir as the most conspicuous one - producing Nordic Noir both from within and beyond the Nordic region. In the near future, we will see how existing Nordic PSBs are able to continue creating trending content, and how well they are able to hold on to it in order to secure the much needed viewership - a viewership presently cutting cable and moving on to online, commercial content providers.

\section{References}

Agger, G. (2011). Adaptioner, spinoffs og selvstændige produktioner: Strategier i svensk og dansk tv-krimi [Adaptations, spinoffs, and independent productions: Strategies in Swedish and Danish television crime]. Kosmorama, 248, 161-179. https://www.kosmorama.org/kosmorama/arkiv/248/adaptioner-spinoffs-og-selvstaendige-produktioner

Arrow Films. (n.d.). Nordic Noir \& Beyond. http://nordicnoir.tv

Bergman, K. (2014). Swedish crime fiction: The making of Nordic Noir. Milano: Mimesis.

Biesen, S. C. (2016). Binge-watching "noir" at home: Reimagining cinematicreception and distribution via Netflix. In K. McDonald, \& D. Smith-Rowsey (Eds)., The Netflix effect: Technology and entertainment in the 21st century (pp. 129-142). New York: Bloomsbury.

Billig, M. (1995). Banal nationalism. London: Sage Publications.

Briel, R. (2018, February 22). MTG's Viaplay unveils streaming figures. Broadband TV News. https://www. broadbandtvnews.com/2018/02/22/mtgs-viaplay-unveils-streaming-figures/

Bruun, H. (2018). Licence fees, platform neutrality, and public service obligation. In D. Johnson (Ed.), From networks to Netflix: A guide to changing channels (pp. 77-84). New York: Routledge. https://doi. org/10.4324/9781315658643

Burch, S. (2013). Banal nordism: Recomposing an old song of peace. In P. Aronsson, \& L. Fradén (Eds.), Performing Nordic heritage: Everyday practices and institutional culture (pp. 129-162). Surrey: Ashgate. https://doi.org/10.4324/9781315599991

Creeber, G. (2013). Killing us softly: Investigating the aesthetics, philosophy and influence of Nordic Noir television. The Journal of Popular Television, 3(1), 21-35. https://doi.org/10.1386/jptv.3.1.21_1.

Danish Film Institute (DFI). (2019). Vilkår for støtte til Public Service Puljen [Terms of support for the public service fund]. https://www.dfi.dk/files/docs/2018-04/Vilk\%C3\%A5r_PSP_1_maj_2016.pdf

Dunleavy, T. (2018). Complex serial drama and multiplatform television. New York: Routledge. https://doi. org/10.4324/9781315682310

European Commission. (2018). Audiovisual media services directive. https://ec.europa.eu/digital-singlemarket/en/audiovisual-media-services-directive-avmsd

Gomez-Uribe, C. A., \& Hunt, N. (2015). The Netflix recommender system: Algorithms, business value, and innovation. ACM Transactions on Management Information Systems, 6(4), 13:1-19. http://dx.doi. org $/ 10.1145 / 2843948$

Hansen, K. T. (2020a). From Nordic Noir to Euro noir: Nordic Noir influencing European SVoD serial drama. In A. Nestingen, J. Seeppälä, \& L. Badley (Eds.), Nordic Noir adaptation and appropriation: Film, television, and beyond. Cham: Palgrave Macmillan. https://doi.org/10.1007/978-3-030-38658-0

Hansen, K. T. (2020b). Glocal perspectives on Danish television drama: Co-producing commercial public service crime dramas. In P. M. Jensen, E. N. Redvall, \& A. M. Waade (Eds.), Danish television drama: Global lessons from a small nation (in press). Basingstoke: Palgrave Macmillan.

Hansen, K. T., \& Waade, A. M. (2017). Locating Nordic Noir: From Beck to The Bridge. Basingstoke: Palgrave Macmillan. https://www.doi.org/10.1007/978-3-319-59815-4

\section{Acknowledgements}

Research presented in this chapter has been financed by the research project DETECt-Detecting Transcultural Identity in European Popular Crime Narratives (Horizon 2020, 2018-2021) [Grant agreement number 770151]. Interviews with Nanna Mailand (2018) and Hanne Palmquist (2018) have been conducted as part of a larger research project on European creative industries within DETECt. Quotes from the interviews (translated by author) have been approved for publications by the interviewees. 
Hjort, M. (2009). On the plurality of cinematic transnationalism. In N. Duurovičová, \& K. Newman (Eds.), World cinemas, transnational perspectives (pp. 12-33). New York: Routledge. https://doi. org/10.4324/9780203882795

Hughes, S. (2018, September 20). The BBC's Bodyguard is becoming a 'Netflix Original'. So who gets the credit? The Guardian. https://www.theguardian.com/commentisfree/2018/sep/20/bbc-bodyguard-netflixoriginal-streaming

Imre, A. (2018). HBO's e-EUtopia. Media Industries, 5(2), 49-68. http://dx.doi.org/10.3998/ mij.15031809.0005.204

Jensen, P. M. (2016). Global impact of Danish drama series: A peripheral, non-commercial creative counterflow. Kosmorama, 263. https://www.kosmorama.org/en/kosmorama/artikler/global-impact-danish-drama-series-peripheral-non-commercial-creative-counter

Johnson, C. (2019). Online TV. New York: Routledge. https://doi.org/10.4324/9781315396828

Johnson, D. (2018). Pop: Television guides and recommendations in a changing channel landscape. In D. Johnson (Ed.), From networks to Netflix: A guide to changing channels (pp. 3-22). New York: Routledge. https://doi.org/10.4324/9781315658643

Lotz, A. (2007). The television will be revolutionized. New York: New York University Press.

McDonald, K., \& Smith-Rowsey, D. (2016). The Netflix effect: Technology and entertainment in the 21st century. New York: Bloomsbury.

Navne, H. (2015, May 21). Er det store stygge Netflix-dyr farligt for film og tv? [Is the big ugly Netflix beast dangerous to movies and TV?] Politiken. https://politiken.dk/magasinet/feature/art5621838/Er-det-storestygge-Netflix-dyr-farligt-for-film-og-tv

Nielsen, J. I. (2016). The Danish way to do it the American way. Kosmorama, 263. https://www.kosmorama. org/en/kosmorama/artikler/danish-way-do-it-american-way

Nordisk Film \& TV Fund. (2019). Retningslinjer [DK] 2019 [Guidelines (DK) 2019]. http://cdn.nordiskfilmogtvfond.com/assets/download/Guidelines_DK_2019.pdf

Nordvision. (2018). Retningslinjer for Nordvision [Nordvision guidelines]. https://www.nordvision.org/ fileadmin/webmasterfiles/Retningslinjer/Retningslinjer_feb_2018.pdf

Norwegian Film Institute (NFI). (2019). Utvikling og produksjon av dramaserie etter konsulentvurdering [Development and production of drama series after consultancy assessment]. https:/www.nfi.no/soktilskudd/dramaserier/konsulentvurdering

Peacock, S. (2014). Swedish crime fiction: Novel, film, television. Manchester: Manchester University Press.

Pham, A. (2018, April 19). Nordic public broadcasters launch 'Nordic 12'. Nordisk Film \& TV Fund. http:// www.nordiskfilmogtvfond.com/news/stories/nordic-public-broadcasters-launch-nordic-12

Ramsey, P. (2017). Commercial public service broadcasting in the United Kingdom: Public service, television, regulation, and the market. Television \& New Media, 18(7), 639-654. https://doi. org/10.1177\%2F 1527476416677113

Roxborough, S. (2018, October 10). Netflix content quota in Europe may lead to TV buying spree. The Hollywood Reporter. https://www.hollywoodreporter.com/news/netflix-content-quota-europe-may-lead-tvbuying-spree-1150805

Saunders, R. A. (2019a). Geopolitical television at the (b)order: liminality, global politics, and world-building in The Bridge. Social \& Cultural Geography, 20(7), 981-1003. https://doi.org/10.1080/14649365.20 17.1404122

Saunders, R. A. (2019b). Small screen IR: A tentative typology of geopolitical television. Geopolitics, 24(3), 691-727. https://doi.org/10.1080/14650045.2017.1389719

Stougaard-Nielsen, J. (2017). Scandinavian crime fiction. New York: Bloomsbury.

Swahnberg, O. (2018, October 4). NENT takes on Netflix in battle for Nordic streaming market as it readies for listing. Reuters. https://www.reuters.com/article/us-mtg-nordic-entertainment-group/nent-takes-onnetflix-in-battle-for-nordic-streaming-market-as-it-readies-for-listing-idUSKCN1ME1SJ

Syvertsen, T., Enli, G., Mjøs, O. J. \& Moe, H. (2014). The Nordic media welfare state: Nordic media in the digital age. Ann Arbor, Michigan: University of Michigan Press. https://www.doi.org/10.1353/book.36850

The Nordic Council of Ministers. (2014). Agreement 2015-2019: Nordic Film \& TV Fund. http://cdn.nordiskfilmogtvfond.com/assets/download/Agreement-of-the-fund-English-translation.docx

Copyright: (C) 2020 The Author(s) and Nordicom. This is an Open Access article distributed under the terms of the Creative Commons Attribution 4.0 International License (CC BY-NC-ND 4.0). 